\title{
Analysis of the Use of Local Resources in Extension Education Programme in Nkonkobe Local Municipality of Eastern Cape
}

\author{
Isaac Azikiwe Agholor ${ }^{1}$, Nomakhaya Monde ${ }^{1} \&$ Akinwumi Sunday Odeyemi $^{2}$ \\ ${ }^{1}$ Department of Agricultural Economics, Extension and Rural Development, University of fort Hare, South \\ Africa \\ ${ }^{2}$ Department of statistics, University of fort Hare, South Africa \\ Correspondence: Isaac Azikiwe Agholor, Department of Agricultural Economics, Extension and Rural \\ Development, University of fort Hare, South Africa. E-mail: isaaco477@yahoo.com
}

Received: December 10, 2012 Accepted: January 16, 2013 Online Published: March 15, 2013

doi:10.5539/jas.v5n4p15 URL: http://dx.doi.org/10.5539/jas.v5n4p15

\begin{abstract}
The paper identified the available local resources for extension education and the constraints in the use of these local resources in Nkonkobe local Municipality. The survey was conducted in the peri-urban areas of Fort Beaufort, Alice, Seymour, Balfour, Hogsback and Middledrift from $7^{\text {th }}$ to $29^{\text {th }}$ September 2010 by interviewing 58 farmers on the identification of local resources and their perception of constraints in the use of local resources. The study revealed that there are local resources embedded in the area for use in Extension teaching and learning. The perception of constraint (inadequate access to local resources) increased significantly with age $(\mathrm{P}=0.04)$ and farm experience $(\mathrm{P}=0.045)$. The fundamental strategies for a successful Extension work should be to develop a process which not only creates co-operative platforms for the use of local resources for rural improvement, but also reinforces farmer's ingenuity and inspires them to learn and accept innovation. The available local resources in Nkonkobe Local Municipality are well distributed in the community and are important for the achievement of educational goals in Extension teaching and learning.
\end{abstract}

Keywords: local resources, farmers, extension, education, identification, programme, constraints

\section{Introduction}

The daunting task of inadequate food production before the marginalized rural farmers must be addressed through identification and use of available local resources. Extension professional must be saddled with the responsibility of bringing to bare the knowledge of local resources for quality Extension education delivery. Rural farmers have the potentials of utilizing local resources optimally to their best advantage (Kumar \& Hansra, 2000). The use of agrarian sector in fighting poverty is important given the accessible infrastructures in the country. In South Africa, several approaches have been used to disseminate technology to the rural farmers, but seemingly the local resources have not been tapped sufficiently by extension officers. The farming community requires assistance from extension service providers to become supportive components of production. It is the priority of the government to empower the rural farmers through policies and programmes that are sustainable. Therefore, it is necessary that the Extension officers should fully identify the local resources in the farming community and enhance its use. In many developing countries, the quality of Extension services has been very low, in terms of relevance, accuracy and applicability to farmers' current situations. Moreover, it has been increasingly difficult for most farmers to realize the value of extension services as most of their programmes are prepared on adhoc basis for interventions (Elena, 2004). According to Sebidi (1997) the reliance of extension officers towards indigenous knowledge and its application and use is discouraging. The extension officers lack the insight of the local structures for involvement and forming links with the farming community. However, as a role player, Extension must be familiar with the stages of technology generation. The initial involvement of Extension and farmers in research activities from the beginning to the end is important to avoid a situation where researchers or Extension are seen as instructive. Farmers have sufficient occupational knowledge coupled with indigenous insight and understanding which are valuable for developing suitable local resources for extension education programme. Folk media are local resources that comprises of native knowledge, experiences and expression which are coin into proverbs and poems, songs and dances, puppet play, storytelling, and drumming that has great influence on adoption of technology (FAO, 1998). Extension can also help in the sustenance of development activities by the 
application of supportive methods using traditional communication channels like folk media. In most local communities, the use of puppets are becoming pronounced as a method of addressing diverse development issues such as teaching children, encouraging technical methods of farming, promotion of and use of pesticides and fertilizers (Persickle, 2007). According to Brennan (2005) farmers are likely to accept solutions to their problems when it is consistent with their indigenous knowledge system. There is strong positive relationship between farmers participation in programme planning and technology adoption. The identification and use of local resources for extension education programme will enhance technology adoption by farmers. It is therefore, the concern of the extension officers to fully integrate and identify the local resources in the community and optimize its use. The overall purpose of this study is to examine the availability of local resources that could be used in extension education programme. The specific objectives are (i) identify the local resources available for use in Extension education programme; (ii) assess farmers' perceptions of various constraints to the use of local resources in Extension education programme.

\section{Methodology}

The survey was carried out in Nkonkobe Local Municipality in Amathole district, it shares border with Nxuba Municipality to the West and Amahlathi municipality to the East (Appendix 1). It has a population of about 130, 101 with average household of 34 890. Nkonkobe has a total land mass of about $3725 \mathrm{~km}$ square. The peri-urban areas in the municipality are Fort Beaufort, Alice, Seymour, Balfour, Hogsback and Middledrift. Majority of the population resides in villages and about $19 \%$ of the population resides in the urban areas (NLM/IPD 2008). Alice and Fort Beaufort are the major business centres in the area. The dominant groups are the black Africans with a population of about $95.3 \%$, followed by the $4.4 \%$ coloured and the $0.3 \%$ white. The major language spoken is Isi Xhosa. Farming activities thrives in almost all parts of the area with diverse terrain and warm temperature. The soil in the area is eutric fluvisol and has low nitrogen, organic matter and phosphorus. The level of exchangeable ions and $\mathrm{PH}$ of about 5.7 makes the area suitable for vegetable production. The areas located in the valley accounts for intensive production of maize, pumpkins, vegetables and fruits with the help of irrigation (SASCA, 1991). Livestock farming in the area is wide spread with large pasture land which recently has been threatened by drought.

\subsection{Methods of Data Collection and Sampling Procedure}

A structured questionnaire aimed at determining the availability and assessing the constraints in the use of local resources for extension education programme among farmers in Nkonkobe Local Municipality was designed in 2010 and the data was collected between $7^{\text {th }}$ to $29^{\text {th }}$ September. The questionnaire was pretested on farmers in the study area and subsequently refined with the addition of few questions. The sample size was 60 randomly selected farmers but only 58 farmers were readily available when the questionnaire was collected. The sample size was selected from the 5 major areas that make up Nkonkobe Local Municipality (Appendix 1). Some farmers were interviewed on the farm while others were interview at home. The respondents' responses to demographic information, identification of available local resources and constraints in the use of local resources for extension programme were recorded. For each question item, the percentages of farmers who gave responses were calculated for the area. For each of the questionnaire item a five- point scale elicited the respondent responses. The assigned values for section A: Very Much $=5$ points, Much $=4$ points, little $=3$ points, Very little $=2$ points, none $=1$ points. The section B of the questionnaire carried five- point scaling item as follows: Most often, Often, Very often, less often, and none. The assigned values for section $\mathrm{C}$ are Strongly Agree $=5$ points, Agree $=4$ points, Disagree $=3$ points, strongly disagree $=2$ points, Undecided $=1$ point. Rating scale was used to determine farmers' perception of constraints. Study identification numbers was assigned to each respondent. This was to maintain respondent anonymity. Raw data collected was entered into Microsoft excel spreadsheet. In addition, data for each respondent was carefully revised for mistakes that could have occurred while entering the data. The data were analyzed using Statistical Analysis System (SAS) 2003.

\section{Results and Discussions}

The section concisely explains and discusses the result of the study as follows: socio-economic characteristics of interviewed farmers, identification of local resources and farmers' perception of constraints in the use of local resources in Extension education programme. 


\subsection{Socio-Economic Characteristics}

Table 1. Socio-economic characteristics of farmers interviewed

\begin{tabular}{ll}
\hline Farmers' characteristics & Summary of responses (\%) \\
\hline Age category (years): & \\
$\leq 30$ & 10.5 \\
$31-40$ & 8.8 \\
$41-50$ & 19.3 \\
$51-60$ & 29.8 \\
$\geq 61$ & 31.6 \\
Gender: & \\
Male & 68.4 \\
Female & 31.6 \\
Marital status: & \\
Married & 47.4 \\
Not married & 36.8 \\
Divorcee & 15.8 \\
Education background: & \\
No school & 5.3 \\
Primary & 19.3 \\
Junior secondary & 35.1 \\
High school & 35.1 \\
Tertiary & 5.3 \\
Land size in hectares: & \\
$\leq 1$ & 3.5 \\
1-5 & 3.5 \\
$6-10$ & 7.0 \\
$11-15$ & 14.0 \\
$16-20$ & 22.8 \\
$\geq 21$ & 49.1 \\
Farm experience in years: & \\
$\leq 5$ & 15.8 \\
$6-10$ & 22.8 \\
$11-15$ & 29.8 \\
$16-20$ & \\
$\geq 21$ & \\
\hline & \\
& \\
&
\end{tabular}

The socio-economic characteristic gives the ages, gender, marital status, and educational background, land size in hectares and farm experience in years of the respondents (Table 1). Majority of the respondents were males (68.4\%) with age range between 31 to 50 years and fewer respondents were aged between 31 to 40 years (Table 1). Majority of the respondents attained junior and high school education (35.1\% and 35.1\%) respectively, while 5.1\% had tertiary education. The respondents that had no formal school education were only $5.3 \%$ indicating that most of the farmers can at least read and write. Majority of the respondents are commercial farmers with land holding size of $49.1 \%$ (Table 1). Some respondents had 3.5\% of land size and were also engaged in other businesses like trading. However, respondents who had a land size of 16 to 20 hectares were $22.8 \%$ while respondents with land 
size of 6 to 10 hectares were 7\%. Majority of the farmers interviewed had farming experience of between 6 to 15 years while farmers that had 16 to 20 years' experience were $15.8 \%$. Nevertheless, $49.1 \%$ of the respondent had more than 21 years of farming experience (Table 1).

\subsection{Identification of Local Resources}

Local resources are those locally available materials, persons, folk media, tradition, indigenous knowledge, organizations, community garden, orchards and farms that are useful and of valuable for agricultural extension education (Kinnerney, 1974). According to Benbrook (1991) indigenous agriculture involves the use of local resources within the community while still maintaining the environment. Harold (1978) in his own view on the need to identify local resources for instruction stated that the community is a good source of instructional materials for Extension education. The result of the study showed that there are local resources available for Extension education in the study area. The respondents interviewed (78\%) identified the following local resources that could be used in Extension education as (i) community livestock (cattle, poultry, sheep); (ii) community garden/crop farm (maize, spinach, cabbages, carrot; (iii) orchards; pineapple, citrus, peas, grape, mango; (iv) Agencies and projects (Research Institutes, Department of Agriculture, Department of Social development); (v) Resource persons; (vi) others (markets, folk media, agro-service centres, and abattoirs). Some respondent $(40 \%)$ asserted that agencies and projects are not accessible to them. The identification of local resources calls for further exploration of the community by Extension officers to discover more of the local resources that can be used in the delivering of Extension education. This result leads credence to the findings by Terblanche (2008) that Extension agent and her organization must identify and recognize local resources for forming of linkages with farmers. Ingenious Extension officers will find the community as a treasure of untapped resources which can be used for effective education for the farmers. Mkpa (1987) asserted that every community, however small or isolated has within it some local resources that can make learning realistic and effective. Results showed that $72.6 \%$ of the respondent agreed that Extension officers do not use the available local resources. The responses from the respondents portrays that majority of the Extension officers do not make exhaustive use of the local resources during their field teaching. This finding agrees with the assertion of Rivera (1995) that Extension resources available to Extension officers are not used exhaustively in developing regions of the world. Research results from earlier studies shows that in Africa, two out of every three farmers have no interaction with public extension services; in Asia three out of four; in Latin America, six out of seven and five out of six in the Near East (Maalouf et al., 1991). Ukoha (1977) stated that farmers are always excited and they show sufficient interest when they are taught using local resources. However, only very little of the available local resources are utilized for extension education in the community. Extension officers need re-orientation to be resourceful in the use of local resources for Extension education.

\subsection{Farmers' Perceptions of Constraints in the Use of Local Resources in Extension Education}

Result of our study indicated that most often local resources are provided by the community. The perception of constraint (inadequate access to local resources) increased significantly with age $(P=0.04)$ and farm experience $(\mathrm{P}=0.045)$ as shown in Table 2 . The respondent $68 \%$ asserted that there are no constraints in discovering the local resources available in the community. However, $35 \%$ of respondents agreed that often there are physical and financial constraints in accessing these local resources. Nevertheless, since the respondent agreed that most of these local resources are obtained and are available within the farming community, the physical or financial constraints are minimal. However, most agro-service centres are within the immediate locality, the Extension officer can organize the farmers into groups for excursion to such centres. Resources in terms of money may not be too much of a burden since the centres are within the local community. In summary, the Extension officer should be able to improvise and form linkage structures within the community to address some of the constraints militating against the use of local resources in Extension education. The urban background of Extension officers and inadequate accountability to the farmers is part of the constraint in the use of local resources.

\subsection{Implication and Recommendation}

The results revealed that there are local resources embedded in the area for use in Extension teaching and learning. However, only very little of the available local resources are utilized for extension education in the farming community. Inadequate access to local resources and Extension officers' attitude were identified by the respondents as major constraints to the use of local resources. Extension planners, supervisors, and government will now be abreast of the possible local resources that could be tapped for Extension education in Nkonkobe Local Municipalities. Another implication is that farmers will be motivated to form concrete opinion on knowledge gained from Extension officers through the use of local resources. The findings of this study will also be useful to 
Government in planning Extension programmes. It will assist in fostering cooperation and linkages between the Extension practitioners and the local community.

Table 2. Results of logistic regression showing relationship between farmers' socio- demographic characteristics and perception of constraints in the use of Local resources

\begin{tabular}{|c|c|c|c|c|c|c|c|c|}
\hline $\begin{array}{l}\text { Dependent } \\
\text { Variable }\end{array}$ & $\begin{array}{c}\text { Farmers' Social } \\
\text { background }\end{array}$ & coefficient & SE & $\begin{array}{c}\text { Wald } \\
\chi^{2}\end{array}$ & P-value & $\begin{array}{l}\text { Odd } \\
\text { ratio }\end{array}$ & $95 \mathrm{CI}$ & \\
\hline \multicolumn{9}{|c|}{ Unaware of the available local resources } \\
\hline & Intercept & -2.8 & 7.016 & 0 & 0.159 & 0.69 & - & - \\
\hline & Age & -0.682 & 0.442 & 2.385 & 0.123 & 0.505 & $0.213-1.202$ & - \\
\hline & Gender & 1.353 & 0.794 & 2.904 & 0.088 & 3.869 & $0.816-18.346$ & - \\
\hline & Marital status & - & - & 3.147 & 0.207 & - & - & - \\
\hline & Education & - & - & 2.308 & 0.679 & - & - & - \\
\hline & Farm experience & 0.235 & 0 & 0.372 & 0.4 & 0.527 & 1.265 & $0.610-2.621$ \\
\hline \multicolumn{9}{|c|}{ Inadequate access to these local resources } \\
\hline & Intercept & 5.689 & 21463.68 & 0 & 1 & - & - & \\
\hline & Age* & -1.185 & 0.578 & 4 & 0.198 & 0.04 & 0.306 & $0.098-0.950$ \\
\hline & Gender & 1.481 & 0.868 & 2.909 & 0.088 & 4.398 & $0.802-24.126$ & \\
\hline & Marital & status & - & - & 0.713 & 0.7 & - & - \\
\hline & Education & - & - & 0.299 & 0.99 & - & - & \\
\hline & Farm experience* & 0.99 & 0 & 0.495 & 4.006 & 0.045 & 2.692 & $1.021-7.101$ \\
\hline \multicolumn{9}{|c|}{ Lack of awareness on the use of local resources for knowledge and information } \\
\hline & Intercept & 2.475 & 20104.03 & 0 & 0 & 1 & - & - \\
\hline & Age & -0.885 & 0.656 & 1.819 & 0.177 & 0.413 & $0.114-1.493$ & \\
\hline & Gender & 1.589 & 1.027 & 2.394 & 0.122 & 4.898 & $0.654-36.655$ & \\
\hline & Marital & status & - & - & 2.109 & 0.348 & - & - \\
\hline & Education & - & - & 3.528 & 0.474 & - & - & \\
\hline & Farm experience* & 1.079 & 0 & 0.55 & 3.856 & 0.05 & 2.942 & $1.002-8.640$ \\
\hline \multicolumn{9}{|c|}{ Distance between local resource centres and homestead/farm } \\
\hline & Intercept & 43.589 & 21329.36 & 0 & 0 & 0.998 & - & - \\
\hline & Age & 0.361 & 0.395 & 0.834 & 0.361 & 1.434 & $0.661-3.111$ & \\
\hline & Gender & 0.084 & 0.731 & 0.013 & 0.908 & 1.088 & $0.259-4.562$ & \\
\hline & Marital status & - & - & 0.736 & 0.692 & - & - & \\
\hline & Education & - & - & 0.149 & 0.997 & - & - & \\
\hline & Farm experience* & -1.096 & 0 & 0.432 & 6.431 & 0.011 & 0.334 & $0.143-0.780$ \\
\hline \multicolumn{9}{|c|}{ Extension officers' attitude to the use of Local resources is not encouraging } \\
\hline & Intercept & 11.888 & 21898.24 & 0 & 0 & 1 & - & - \\
\hline & Age* & -0.872 & 0.415 & 4.411 & 0.036 & 0.418 & $0.185-0.943$ & \\
\hline & Gender & 0.062 & 0.709 & 0.008 & 0.93 & 1.064 & $0.265-4.273$ & \\
\hline & Marital & status & - & - & 0.036 & 0.982 & - & - \\
\hline & Education & - & - & 1.061 & 0.9 & - & - & \\
\hline & Farm experience* & 0.706 & 0 & 0.381 & 3.432 & 0.046 & 2.026 & $0.960-4.276$ \\
\hline
\end{tabular}

\footnotetext{
*significant $P \leq 0.05$.
} 


\subsection{Recommendation}

Since local resources are available in the community, the Extension officer should explore and effectively utilize the local resources for the benefit of the farmers in their areas of operation. Extension services providers (Government, private, NGO'S) must liaise with the community so as to access the potential available local resources within the community that are useful for farmers' training. Extension officers must be encouraged through training on the use of local resources.

\section{Conclusion}

From the findings of the study, local resources are available in the farming community for use in Extension teaching and learning. However, the available local resources utilized for extension education in the farming community are negligible. Inadequate access to local resources and Extension officers' attitude were also identified as constraints. The utilization of local teaching resources is commendable for effective Extension education programme. In conclusion, the New Economic Partnership for African Development (NEPAD) has identified agriculture as the means through which communities will have to alleviate its own poverty problems. Farmers form concrete experiences of learning outcome when local materials are used for instructions. The fundamental strategies for a successful extension work should be to develop a process which not only creates co-operative platforms for the use of local resources for rural livelihood improvement, but also reinforces farmer's ingenuity and inspires them to learn and accept innovation. Therefore, extension officers should be encouraged to surmount the obstacle against the use of local resources in Extension education. The available local resources available in Nkonkobe Local Municipality are well distributed in the community and are important for the achievement of educational goals in Extension teaching and learning. Manfred (2004) stated that the use of local resources promotes learning activities and also help to strengthen the weak farming communities. In sum, the use of local resources in Extension education makes teaching instructions more effective.

\section{References}

Benbrook, C. M. (1991). Introduction, in sustainable Agricultural Research and Education in the field. National Research Council. Washington D.C.: National Academy press.

Brennan, M. A. (2005). The Importance of Incorporating Local culture into Community development. EDIS Florida Cooperative Extension service. University of Florida. Retrieved 10 October, 2012, from http://edis.ifas.ufl.edu/pdf Accessed 21/09/12

Elena, M. T. (2004). Perception of livestock Extension Education delivery and Globalization Effects among Dairy Farmers in the North Coast of Honduras. Published M.Sc. thesis, Graduate School of the University of Florida. Retrieved 14 September, 2012, from http://www.etd.fc/a/uf/ufE0007521/toro-pdf

FAO. (1998). Report of the Global Consultation on Agricultural Extension. Rome: FAO.

Harold, M. D. (1978). The Utilization of Community Resources for Student Learning In Rural Schools. India: Indiana State University Press.

Kinnerney, M. C. (1974). The Teacher and the Use of Community Resources. Florida: Florida State University.

Kumar, B., \& Hansra, B. S. (2000). Extension Education for human resource Development. New Delhi, India: Group publisher company.

Maalouf, W. D., Adhikarya, R. T., \& Contado, T. (1991). Extension Coverage and Resource Problems: The Need for Public- Private Cooperation. In W. Rivera, \& D. F. Gustafson (Eds.), Agricultural Extension: World wide Institutional Evolution and Forces for Change. New York: Elsevier Science Publisher.

Manfred, W. (2004). Innovative Training for Poverty Reduction in Rural Central Asia. Retrieved 12 May 2012, from http://www.etf.europa.eu./etfblog.nsf

Mkpa, M. A. (1987). Curriculum Development and implementation. Owerri: Totan Printing Press Limited. Nkonkobe Municipality. 2008-2009. IDP (Integrated Development Plan). Unpublished.

Persickle, M. A. (2007). Traditional and Folk Media for Development: Discussion forum hosted by the Communication Initiative. Retrieved from http://forum.comminit.com/viewforum.php?f=49\&style=2

Rivera, W. M. (1995). Human Resources Development in Agriculture Sector. Retrieved June, 2010, from $\mathrm{http} /$ wwww.agnr.umd.edu/users/rivera/1.htm

Sebidi. (1997). Sustainable Extension. In Extension Strategies for Agricultural and Rural Development in Africa. South Africa Society of Agricultural Extension, 112-116. 
South Africa Soil Classification System (SASCS). (1991).

Terblanche, S. E. (2008). Towards an Improved Agricultural Extension Service as a Role Player in the Settlement of New Farmers in South Africa. S. Afr.J. Agric. Ext. Vol., 37, 58-84.

Ukoha, K. U. (1977). A Study of Teachers Use of Resources in the Teaching of Economics in Schools. Unpublished B.Sc Thesis. University of Nigeria, Nsukka.

Appendix 1. Map of Nkonkobe Local Municipality

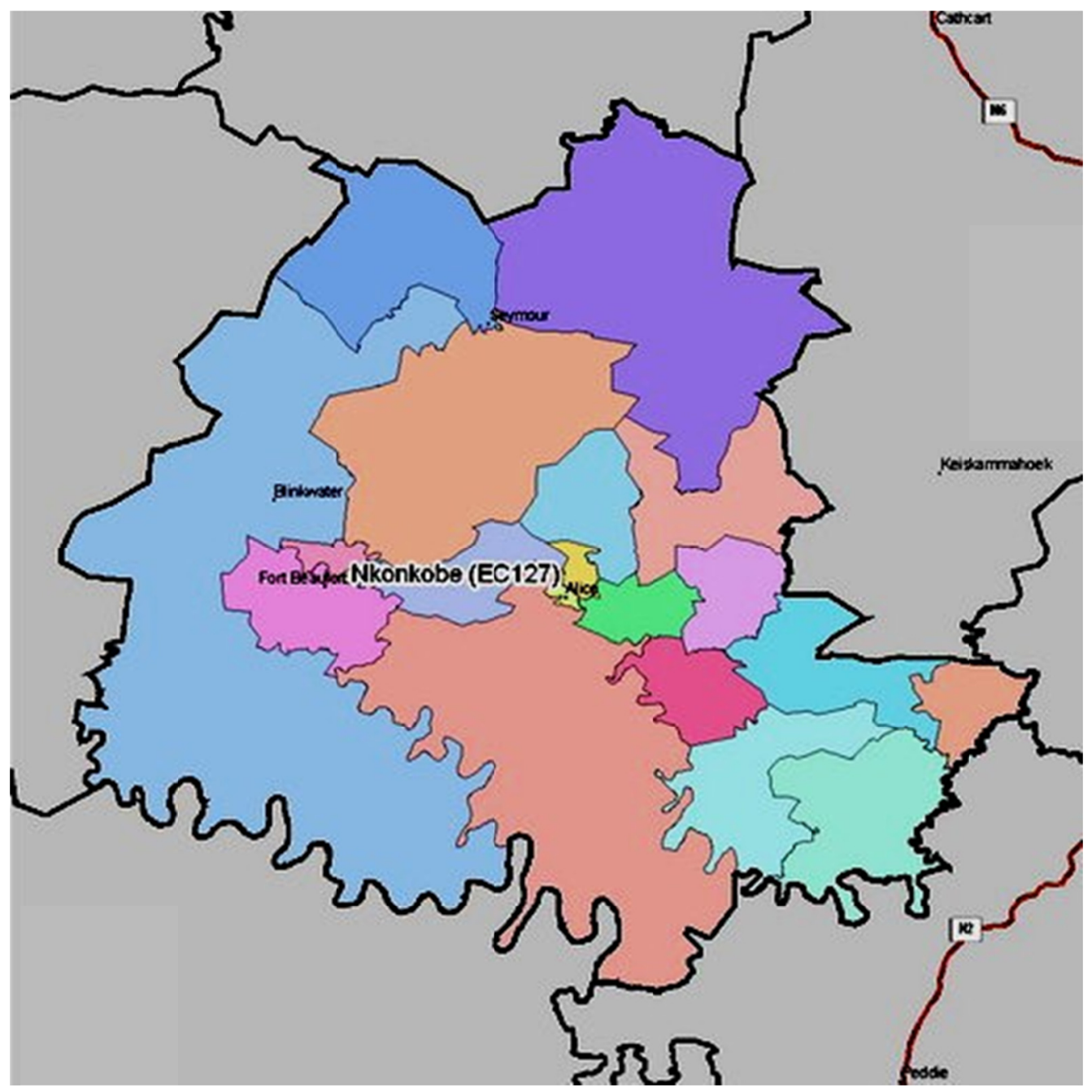

Source: Nkonkobe Local Municipality website 2012. 